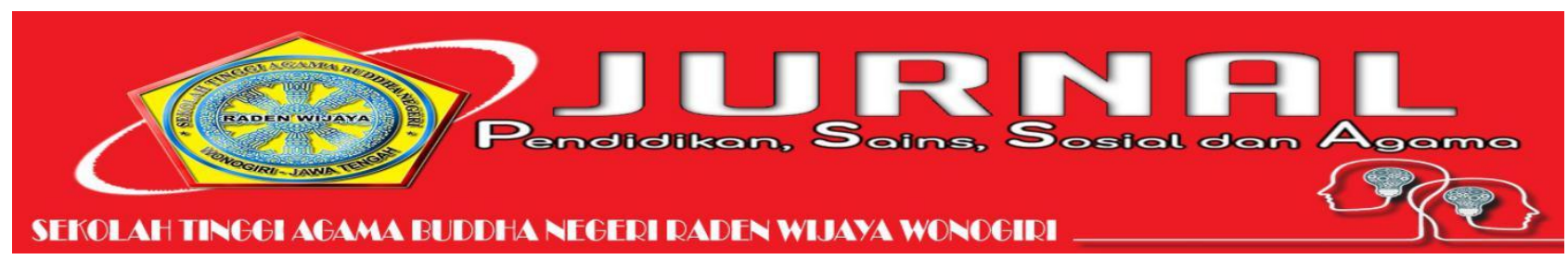

\title{
ANALISIS PEMBELAJARAN DARING TERHADAP HASIL BELAJAR SISWA PADA MATA PELAJARAN PENDIDIKAN AGAMA BUDDHA (Studi Kasus di SMA Bhakti Karya Kecamatan Kaloran, Kabupaten Temanggung)
}

Tito Pariatno, Hesti Sadtyadi, Walyono.

\author{
SEKOLAH TINGGI AGAMA BUDDHA NEGERI RADEN WIJAYA \\ WONOGIRI JAWA TENGAH \\ titopariatno@gmail.com
}

\begin{abstract}
ASTRACT
This study aimed to analyze the implementation of online learning and to describe student learning outcomes in the subject of Buddhist Education at Bhakti Karya High School, Temanggung Regency. This study uses a qualitative research method with a case study approach. The subjects of this study were tenth grade and eleventh grade students of Bhakti Karya High School Kaloran, Temanggung Regency. Data collection techniques in this study were conducted through interviews, observation, and documentation. The results of this study indicated that the implementation of online learning on the subject of Buddhist Education at Bhakti Karya Kaloran High School had been going quite well. There were inhibiting factors when doing online learning, such as the uneven distribution of supporting facilities and the lack of student motivation when they learn online so this learning was still less effective. Students' learning outcomes had decreased due to several influencing factors such as uneven support facilities, the presence of students scattered in several places with minimal signal, students' difficulty in understanding material given, students' awareness on their responsibilities in doing assignments, and lack of environmental factors around student are lacking support. So that it causes a decrease in achievement of student learning outcome during online learning.
\end{abstract}

Keywords: Online Learning, Obstacle Factor, Learning Outcomes.

\begin{abstract}
ABSTRAK
Penelitian ini bertujuan untuk melakukan analisis bagaimana pelaksanaan pembelajaran daring dan mendeskripsikan bagaimana hasil belajar siswa pada mata pelajaran Pendidikan Agama Buddha di SMA Bhakti Karya Kabupaten Temanggung. Penelitian ini menggunakan metode penelitian kualitatif dengan pendekatan studi kasus. Subjek yang diambil dalam penelitian ini adalah siswa kelas X dan XI di SMA Bhakti Karya Kaloran Kabupaten Temanggung. Teknik pengumpulan data dalam penelitian ini dilakukan melalui wawancara, observasi, dan dokumentasi. Hasil dari penelitian ini menunjukkan bahwa pelaksanaan pembelajaran daring pada mata pelajaran Pendidikan Agama Buddha di SMA Bhakti Karya Kaloran sudah berjalan dengan cukup baik. Adanya faktor penghambat saat pembelajaran daring seperti belum meratanya fasilitas pendukung dan masih kurangnya motivasi siswa saat pembelajaran daring sehingga pembelajaran masih kurang efektif. Hasil belajar siswa mengalami penurunan karena beberapa faktor yang mempengaruhi seperti fasilitas pendukung yang belum merata, keberadaan siswa tersebar dibeberapa tempat yang minim signal, siswa kesulitan dalam memahami materi, kesadaran siswa akan tanggungjawabnya dalam mengerjakan tugas masih kurang, dan faktor lingkungan di sekitar siswa yang kurang mendukung. Sehingga menyebabkan menurunnya capaian hasil belajar siswa pada saat pembelajaran daring.
\end{abstract}

Kata Kunci: Pembelajaran Daring, Faktor Penghambat, Hasil Belajar. 


\section{PENDAHULUAN}

\section{PENDAHULUAN}

Pendidikan sebagai sarana untuk meningkatkan kualitas kehidupan dan kemampuan seseorang yang berlangsung secara bertahap dan berproses, dalam proses pendidikan itu seseorang mulai belajar mengembangkan pengetahuan, tanggung jawab atau merubah perilaku ke arah yang lebih kompleks sehingga bermanfaat bagi diri sendiri maupun orang lain. Menurut UndangUndang Republik Indonesia Nomor 20 tahun 2003, didefinisikan bahwa pendidikan adalah upaya yang sadar dan terorganisir untuk menciptakan suatu lingkungan belajar dan siklus belajar sehingga siswa secara aktif akan mengembangkan potensi yang ada dalam dirinya untuk memiliki kekuatan spiritual keagamaan, pengendalian diri, kepribadian, kecerdasan, akhlak mulia, serta keterampilan yang diperlukan dirinya, masyarakat, bangsa, dan negara.

Pendidikan sangat berperan dalam mewujudkan manusia yang utuh dan mandiri, berakhlak mulia serta bermanfaat bagi lingkungannya. Lingkungan keluarga adalah lingkungan pertama memberikan pendidikan, karena dalam keluarga seorang anak pertama kali mendapatkan pendidikan dan pengalaman. Pengalaman yang diperoleh anak melalui pendidikan keluarga sangat mempengaruhi perkembangan anak selanjutnya. Lembaga pendidikan selanjutnya adalah sekolah. Sekolah merupakan suatu lembaga yang digunakan untuk kegiatan belajar mengajar bagi guru dan siswa, serta menjadi tempat memberikan dan menerima pelajaran yang sesuai dengan bidangnya. Sekolah sebagai tempat untuk kegiatan belajar mengajar memiliki kedudukan yang penting dalam menjadikan kehidupan manusia menuju ke arah yang lebih baik.

Pada tahun 2020 sekolah memasuki tahun ajaran semester genap, sekolah yang seharusnya lebih gencar dalam melaksanakan kegiatan pembelajaran untuk mencapai target diakhir semester. Namun karena adanya musibah pandemi virus COVID-19 (corona virus disease 2019) yang mewabah di Indonesia bahkan dunia tepatnya pada awal Maret menimbulkan dampak yang sangat besar hampir pada semua sektor, salah satunya adalah dunia pendidikan. Hal tersebut menyebabkan pemerintah harus mengeluarkan keputusan work from home (bekerja dari rumah), untuk mencegah penyebaran wabah COVID-19.

Penerapan work from home juga berimbas pada kegiatan pelaksanaan pembelajaran sehingga Kemendikbud harus menetapkan aturan study from home (belajar dari rumah) sesuai dengan Surat Edaran Kemendikbud RI No.3 Tahun 2020 tentang Pencegahan COVID-19 pada satuan Pendidikan. Kegiatan belajar mengajar tetap dilaksanakan dari rumah masing-masing dengan sistem pembelajaran daring (dalam jaringan). Pembelajaran daring merupakan 
sebuah pembelajaran yang dilakukan secara jarak jauh melalui jaringan internet dan alat penunjang lainnya seperti laptop/komputer maupun telepon seluler (Putria, dkk., 2020: 863).

Pembelajaran daring lebih menekankan pada ketelitian dan kejelian siswa dalam menerima dan mengolah informasi yang disajikan secara daring atau online, dalam pembelajaran daring kemandirian siswa sangat berpengaruh pada keberhasilan belajar (Riyana, 2019: 14). Penerapan pembelajaran daring sangat berpengaruh terhadap kondisi para siswa. Proses pembelajaran yang dilakukan secara daring menimbulkan dampak pada siswa. Selama pembelajaran daring diberlakukan banyak siswa yang mengeluhkan beberapa kendala yang dialami. Kendala yang dialami selama belajar dari rumah seperti fasilitas pendukung pembelajaran daring yang kurang mumpuni. Pembelajaran yang baik hendaknya tersedia fasilitas belajar yang memadai, antara lain seperti; ruang tempat belajar, penerangan cukup, buku-buku pegangan, kelengkapan peralatan, ketersediaan gawai, laptop/komputer, handphone, kuota internet dan jaringan internet yang stabil.

Adapun kendala dan masalah yang dialami oleh siswa dalam pembelajaran daring antara lain: kurangnya fasilitas pendukung dalam pembelajaran daring, kemampuan belajar mandiri siswa yang masih rendah, siswa merasa bosan dan jenuh, siswa kesulitan dalam memahami materi yang diberikan oleh guru, dan kurangnya motivasi siswa dalam melalukan pembelajaran. Motivasi belajar siswa yang rendah dalam pembelajaran daring ditunjukan dengan siswa menjadi malas mengerjakan tugas, cendurung telat mengumpulkan tugas, tidak mengumpulkan tugas yang sudah diberikan, bahkan ada beberapa siswa yang sama sekali tidak pernah mengumpulkan tugas yang diberikan, sehingga nilai untuk mata pelajaran Pendidikan Agama Buddha mengalami penurunan.

Berdasarkan kondisi yang terjadi di atas tentang masalah-masalah yang dihadapi siswa pada saat pembelajaran daring. Melihat kondisi tersebut, maka peneliti tertarik untuk meneliti tentang analisis pelaksanaan pembelajaran daring terhadap hasil belajar siswa. Sehingga peneliti ingin meneliti masalah yang ada dengan judul penelitian "Analisis Pembelajaran Daring Terhadap Hasil Belajar Siswa Pada Mata Pelajaran Pendidikan Agama Buddha (Studi kasus di SMA Bhakti Karya Kecamatan Kaloran, Kabupaten Temanggung)".

\section{LANDASAN TEORI}

Menurut Isman (2017: 587) pembelajaran daring merupakan suatu kegiatan pembelajaran yang memanfaatkan jaringan internet saat pelaksanaannya. Secara pelaksanaan pembelajaran daring dilakukan secara jarak jauh, sehingga dapat menjadi solusi pembelajaran ketika terjadi bencana alam atau kondisi yang mengharuskan social 
distancing (Syarifudi, 2020: 31). Sedangkan menurut Putria dkk (2020: 863) Pembelajaran daring adalah sebuah pembelajaran yang dilaksanakan dalam jarak jauh melalui media berupa internet dan alat penunjang lainnya seperti telepon seluler dan komputer.

Berdasarkan definisi di atas dapat disimpulkan pembelajaran daring adalah suatu kegiatan pembelajaran yang dalam pelaksanaanya menggunakan jaringan internet. Kegiatan belajar mengajar yang dilakukan secara jarak jauh melalui media berupa internet dan alat penunjang seperti; telepon seluler, laptop, komputer, dan sebagainya. Pembelajaran daring dapat dilakukan melalui berbagai aplikasi yang dapat menunjang proses pembelajaran seperti Google Classroom, WhatsApp Group, Google Meet, Zoom dan lain sebagainya. Pembelajaran daring ini sangat jauh berbeda dengan pembelajaran konvensional yang seperti biasa dilakukan secara langsung di sekolah. pembelajaran daring lebih fleksibel dan praktis karena tidak terbatas waktu dan tempat, guru dan siswa tidak perlu melakuakan interaksi secara langsung atau tatap muka akan tetapi bisa berinteraksi secara tidak langsung melalui media internet.

Pembelajaran daring memiliki kelebihan dan kekurangan. Pembelajaran daring memiliki beberapa kelebihan antara lain; pertama memiliki pilihan untuk membangun korespondensi dan percakapan yang sangat mahir antara guru dan siswa, kedua siswa dapat lebih leluasa berkolaborasi dan berbicara antara satu siswa dengan yang lainnya tanpa melalui guru, ketiga komunikasi antara siswa, guru dan orang tua siswa lebih leluasa tanpa terbatas waktu dan tempat, keempat metode yang sesuai untuk tes dan ujian, kelima guru lebih mudah dan efesien dalam memberikan materi kepada siswa seperti gambar dan rekaman, selain itu siswa juga dapat mendownload materi pembelajaran, dan keenam dapat memudahkan guru untuk memberikan bahan ajar dimanapun dan kapanpun (Sobron dkk, 2019: 2). Sedangkan kelebihan pembelajaran daring/e-learning menurut Yodha, dkk (2019: 183) yaitu; proses log-in yang sederhana memudahkan mahasiswa dalam memulai pembelajaran berbasis e-learning, materi yang ada e-learning telah disediakan sehingga mudah diakses oleh pengguna, proses pengumpulan tugas dan pengerjaan tugas dilakukan secara online melalui google docs ataupun form sehingga efektif untuk dilakukan dan dapat menghemat biaya, pembelajaran dapat dilakukan kapan saja dan dimana saja.

Pembelajaran daring juga memiliki kekurangan, adapun kekurangan pembelajaran daring menurut Pangondian (2019: 57) menyebutkan beberapa kelemahan dalam pelaksanaan pembelajaran daring yaitu; kurang cepatnya umpan balik yang dibutuhkan dalam kegiatan belajar mengajar, pengajar perlu waktu lebih lama untuk mempersiapkan diri, terkadang membuat beberapa orang merasa tidak nyaman, adanya 
kemungkinan muncul perilaku frustasi, kecemasan dan kebingungan. Sedangkan kekurangan pembelajaran daring/e-learning menurut Yodha, dkk (2019: 183) antara lain yaitu; tampilan halaman login yang masih lama memerlukan petunjuk lebih dalam, materi yang diberikan kurang luas dan disajikan dalam bentuk bahasa Inggris sehingga dalam mempelajarinya terbilang merepotkan, adanya pengumpulan tugas yang tidak terjadwal serta tidak adanya pengawasan secara langsung atau dengan tatap muka dalam pengerjaan tugas yang membuat pengumpulan tugas menjadi molor, materi pembelajaran menjadi kurang dimengerti saat pembelajaran tidak ditunjang dengan penjelasan dari guru secara langsung.

Berdasarkan penjelasan di atas dapat disimpulkan bahwa pembelajaran daring/elearning memiliki kelebihan dan kekurangan dalam proses pelaksanaan kegiatan pembelajaran berbasis jaringan atau web. Kelebihan dari pembelajaran daring yaitu mempermudah proses kegiatan belajar mengajar, pembelajaran lebih fleksibel bisa dilakukan dimana saja dan kapan saja, mudahnya dalam mengakses materi pembelajaran, melatih siswa untuk lebih mandiri, serta pengumpulan tugas secara online.

Adapun kekurangan dari pembelajaran daring yaitu tidak adanya pengawasan yang intens karena kegiatan pembelajaran dilaksanakan secara online tanpa tatap muka secara langsung, jika siswa tidak mampu belajar mandiri dan memiliki motivasi belajar yang rendah, maka ia akan sulit mencapai tujuan pembelajaran serta kurang paham terhadap materi yang diajarkan oleh guru, dan pengumpulan tugas yang tidak terjadwalkan.

Proses pelaksanaan pembelajaran daring memiliki faktor pendukung dan faktor penghambat. Adapun faktor pendukung guru dalam proses pembelajar daring menurut Putria dkk (2020:861-872) yaitu; ketersedianya gawai seperti handphone android, laptop, kuota dan jaringan internet yang stabil dan baik. Handphone menjadi faktor yang utama dalam pembelajaran daring karena tanpa adanya handphone pembelajaran tidak dapat terlaksana. Selain itu Purwanto, dkk (2020: 7) mengungkapkan bahwa fasilitas ini sangat penting untuk kelancaran proses belajar mengajar, seperti laptop, komputer ataupun handphone yang akan memudahkan guru untuk memberikan materi belajar mengajar secara daring. Sedangkan faktor penghambat dalam pelaksanaan pembelajaran daring diantaranya: 1) faktor penghambat dalam pembelajaran daring belum semua peserta didik memiliki handphone, 2) adanya rasa malas pada peserta didik pada saat mengerjakan tugas, meskipun sudah didukung dengan fasilitas yang menunjang pembelajaran, 3) masih banyak orang tua yang sibuk bekerja sehingga tidak dapat sepenuhnya membimbing peserta didik dalam pembelajaran (Putria, dkk., 2020: 870).

Selain itu Purwanto dkk (2020: 7) mengungkapkan bahwa faktor penghambat 
dari pembelajaran daring ialah guru tidak bisa menjelaskan secara maksimal karena perubahan cara dan sistem pembelajaran. Butuh waktu untuk beradaptasi bagi guru, orang tua, maupun siswa. Guru, orang tua, dan siswa sendiri terbiasa dengan budaya interaktif secara langsung seperti bercanda dengan teman dan melakukan metode pembelajaran yang bervariasi, maka peserta didik harus beradaptasi dan menerima perubahan baru yang secara langsung akan berpengaruh terhadap kemampuan dan daya serap peserta didik.

Berdasarkan penjelasan-penjelasan di atas dapat simpulkan bahwa dalam proses kegiatan pembelajaran daring ada faktor pendukung dan faktor penghambat. Faktor pendukung dalam proses kegiatan pembelajaran daring ketersedianya gawai seperti handphone android, laptop, kuota dan jaringan internet yang stabil dan baik, selain faktor pendukung dalam proses kegiatan pembelajaran daring, terdapat juga faktor penghambat seperti; belum semua siswa memiliki gawai yang memadai, jaringan internat yang kurang stabil, rendahnya daya beli kuota internet, dan kurangnya motivasi dalam pembelajaran daring. Hal ini menyebabkan hasil belajar siswa menjadi tidak maksimal.

Hasil belajar adalah sebuah pencapaian yang diperoleh siswa dalam proses dan kegiatan pembelajaran dari awal sampai akhir, dibuktikan dengan pencapaian yang diperoleh siswa dengan melibatkan aspek pengetahuan, sikap, maupun keterampilan. Menurut Dimyati dan Mudjiono (2013: 3) hasil belajar adalah hasil dari suatu interaksi tindak belajar dan tindak mengajar. Seseorang dikatakan telah berhasil dalam belajar jika terjadi perubahan tingkah laku pada orang tersebut, misalnya dari tidak tahu menjadi tahu, dari tidak bisa menjadi bisa atau mahir, dan tidak mengerti menjadi mengerti.

Keberhasilan belajar dan latihan dalam Anguttara Nikaya II, 160 ditandai dengan pengertian dan ketrampilan (patisambhida) dalam hal: 1) Memahami maksud dan tujuan, mampu menjelaskan dan menjabarkan secara rinci, dan mampu mempertimbahkan konsekuensinya; 2) Memahami inti sari atau mampu merangkum, dan menganalisis atau dapat menunjukkan penyebabnya; 3) pandai dalam memilih kata atau menggunakan tutur kata yang tepat dalam menyampaikan sesuatu dan mudah untuk dipahami dengan benar; 4) ketangkasan dalam cara mengatasi dan menyelesaikan sebuah masalah yang muncul secara mendadak (Mukti, 2003: 328).

\section{METODE}

Penelitian ini termasuk ke dalam penelitian kualitatif dengan pendekatan studi kasus. Penelitian studi kasus merupakan sebuah pendekatan penelitian yang meneliti fenomena kontemporer secara utuh dan menyeluruh pada kondisi yang sesungguhnya, dengan menggunakan berbagai sumber data 
(Gunawan, 2015: 121). Penelitian ini dilakukan bermaksud untuk mengetahui dan mendeskripsikan secara rinci mengenai proses pelaksanaan pembelajaran daring dan hasil belajar siswa pada mata pelajaran Pendidikan Agama Buddha di Sekolah Menengah Atas (SMA) Bhakti Karya Kecamatan Kaloran, Kabupaten Temanggung. Penelitian ini berfokus pada siswa yang beragama Buddha kelas X dan XI di SMA Bhakti Karya Kaloran. Metode pengumpulan data dalam penelitian ini adalah teknik observasi, wawancara dan dokumentasi. Uji validitas data penelitian ini dilakukan dengan triangulasi. Triangulasi adalah teknik pemeriksaan keabsahan data dengan memanfaatkan sesuatu yang lain diluar data tersebut untuk keperluan pengecekan atau pembanding terhadap data yang bersangkutan (Nugrahani, 2014: 115). Teknik analisis data dalam penelitian ini menggunakan teknik analisis Miles dan Huberman yaitu: pengumpulan data, reduksi data, penyajian data, dan penarikan kesimpulan (verifikasi).

\section{HASIL DAN PEMBAHASAN}

Berdasarkan hasil observasi, wawancara, dan dokumentasi di SMA Bhakti Karya Kaloran maka dapat peneliti analisis dalam bentuk deskriptif, yaitu pencarian fakta dari rumusan masalah dan interpretasi pada landasan teori yang ada. Data-data yang telah didapat benar-benar berasal dari sumber yakni tempat penelitian dan hasil analisis wawancara penulis dari beberapa informan yang dibutuhkan peneliti dan sesuai dengan rumusan masalah yang diangkat. Berikut data pembahasan tentang analisis pembelajaran daring terhadap hasil belajar siswa pada mata pelajaran Pendidikan Agama Buddha (studi kasus di SMA Bhakti Karya Kecamatan Kaloran, Kabupaten Temanggung).

\section{Pelaksanaan Pembelajaran Daring} Pada Mata Pelajaran Pendidikan Agama Buddha di SMA Bhakti Karya Kaloran Kabupaten Temanggung.

Pembelajaran daring atau dalam jaringan adalah proses pembelajaran yang dilakukan secara online dengan menggunakan aplikasi pembelajaran maupun jejaring sosial yang terhubung dengan jaringan internat. Sekolah Menengah Atas Bhakti Karya Kaloran menerapkan pembelajaran daring dimasa pandemi Covid-19 guna untuk mencegah penyebaran virus corona dan sesuai peraturan pemerintah. Sebelum melalukan proses kegiatan belajar mengajar guru tentunya mempersiapkan RPP (Rencana Pelaksanaan Pembelajaran) sesuai dengan kurikulum yang diterapkan di SMA Bhakti Karya Kaloran yaitu kurikulum 2013. Pelaksanaan pembelajaran daring sangat berbeda dengan pembelajaran secara langsung atau tatap muka, yang biasanya guru memberikan materi pelajaran kepada siswa secara langsung di kelas dan harus beralih dengan pelaksanaan pembelajaran secara daring 
dengan menggunakan salah satu media komunikasi yaitu whatsapp.

Guru membuat grup whatsapp sesuai dengan mata pelajaran yang diampu dimasing-masing kelas dan menambahkan siswa ke grup yang sudah dibuat agar memudahkan dalam berkomunikasi dan memberikan materi yang akan diajarkan. Materi diberikan oleh guru melalui grup whatsapp dengan mengirim materi yang diajarkan dalam bentuk powerpoint, pdf, word, maupun video. Penjelasan materi diberikan oleh guru dengan menggunakan fitur voice note. setelah guru selesai menjelaskan materi pembelajaran siswa mendengarkan penjelasan yang diberikan, apabila ada siswa yang masih belum paham dengan materi, maka siswa diberikan kesempatan untuk bertanya di grup whatsapp maupun bertanya secara chat pribadi kepada guru yang bersangkutan. Apabila sudah tidak ada pertanyaan lagi tentang materi, maka selanjutnya siswa diberikan tugas setelah menyimak materi yang sudah dijelaskan.

$$
\text { Adapun rincian tentang }
$$

pelaksanaan pembelajaran daring yang dilakukan siswa beragama Buddha kelas X dan XI di SMA Bhakti Karya Kaloran sebagai berikut:

\section{a. Aplikasi saat pembelajaran daring}

$\begin{array}{llr}\text { Pada } & \text { proses } & \text { kegiatan } \\ \text { pembelajaran daring, } & \text { berbagai } \\ \text { platform dapat digunakan } & \text { secara } \\ \text { efektif baik itu berupa aplikasi, }\end{array}$

website, jejaring sosial maupun learning management system (LMS). Platform yang ada dapat digunakan untuk memfasilitasi pembelajaran seperti sebagai media penyampaian materi, penilaian, ataupun sekedar mengumpulkan tugas. Desain media pembelajaran seharusnya didasari pada karakter dan gaya belajar siswa yang sangat beragam (Widodo et al., 2021). Berdasarkan observasi yang telah dilakukan peneliti pembelajaran daring dilakukan oleh siswa beragama Buddha di SMA Bhakti Karya Kaloran dengan melalui aplikasi whatsapp. di mana guru membuat grup kelas agar memudahkan dalam berkomunikasi dan dapat melalukan proses pembelajaran dengan memberikan materi-materi maupun tugas melalui grup kelas yang sudah dibuat. Alasan utama menggunakan aplikasi whatsapp, karena melihat keberadaan siswa yang tersebar di berbagai wilayah yang berbeda-beda dalam kemampuan mengakses internet dan rata-rata berada di daerah yang minim akses internet. Alasan selanjutnya whatsapp sudah biasa digunakan sehari hari dalam berkomunikasi sehingga sudah paham dalam pengoperasiannya, memudahkan dalam pemberian materi dan tugas-tugas kepada siswa dan aplikasi whatsapp tergolong ringan 
tidak begitu menguras paket data yang besar pada saat penggunaan.

b. Alokasi waktu dan sistem pengumpulan tugas

Pelaksanaan pembelajaran secara daring untuk alokasi waktunya tentu berbeda dengan pembelajaran secara tatap muka langsung di sekolah, pada saat pembelajaran daring untuk alokasi waktu proses belajar mengajar lebih fleksibel, yang mana kalau biasanya pembelajaran secara normal tatap muka itu sampai dengan pukul 14.20 WIB dan pada saat pembelajaran daring diterapkan hanya sampai pukul 12.25 WIB menyesuaikan dengan kondisi yang ada. Sistem pengumpulan tugas menyesuaikan dengan masing-masing guru Mapel, ada yang pengumpulan tugas secara online maupun pengumpulan tugas secara offline dengan datang langsung ke sekolah. Sedangkan sistem pengumpulan tugas tergantung dengan guru mapel masing-masing, ada yang dikumpulkan secara langsung datang ke sekolah dengan mematuhi protokol kesehatan maupun mengumpulkan tugas secara online seperti tugas yang sudah selesai dikerjakan difoto lalu dikirimkan ke guru.

c. Metode yang digunakan saat pembelajaran daring
Metode yang digunakan guru pada saat pembelajaran daring adalah dengan menggunakan metode ceramah dan penugasan disaat melakukan pembelajaran melalui grup whatsapp. Metode ceramah digunakan untuk menerangkan materi yang sudah diberikan melalui grup seperti dalam bentuk powerpoint, pdf, maupun word, lalu guru memberikan penjelasan menggunakan fitur voice note tentang materi yang akan dipelajari agar siswa lebih mudah dalam memahami materi pembelajaran, setelah selesai menjelaskan materi siswa dipersilahkan untuk bertanya apabila masih ada yang belum paham tentang materi yang diberikan. Selanjutnya penugasan, diakhir pembelajaran guru akan memberikan tugas sebagai evaluasi sejauhmana pemahaman siswa tentang materi yang sudah dipelajari. Tugas yang diberikan tidak seperti pada pembelajaran tatap muka secara langsung. Pada saat pembelajaran daring siswa diberikan tugas tidak terlalu banyak karena menyesuaikan dengan kondisi yang ada dan guru tidak boleh terlalu membebani siswa dengan memberikan tugas yang terlalu banyak.

\section{d. Kemandirian siswa pada saat pembelajaran daring}




\begin{tabular}{llll}
\multicolumn{2}{c}{ Kemandirian siswa dalam } & menghargai waktu, dan masih \\
pembelajaran $\quad$ daring & sangat & kurangnya inisiatif siswa mengikuti \\
dibutuhkan agar & siswa mempunyai & pembelajaran daring.
\end{tabular}
tanggung jawab dalam mengatur dan mendisiplikan dirinya untuk mengembangkan kemampuan belajar atas kemauan sendiri. Kemandirian ini menitikberatkan pada proses dalam belajar yang penuh dengan rasa tanggung jawab dan semangat yang kuat sehingga mampu mencapai hasil belajar yang baik. Secara keseluruhan kemandirian belajar siswa dapat dikatakan masih rendah. Hal ini dibuktikan saat proses pembelajaran dilakukan siswa cenderung mengabaikan, tidak memperhatikan materi dan tugas-tugas yang diberikan, mereka lebih memilih untuk bermain game daripada mengerjakan tugas. Keaktifan siswa saat belajar daring cenderung menurun dibandingkan dengan pembelajaran tatap muka, sehingga siswa kurang memamahi materi yang diberikan oleh guru.

Adapun hambatan yang dialami siswa selama mengikuti proses pembelajaran daring adalah disebabkan karena faktor dalam diri siswa sendiri. Faktor tersebut diantaranya: kurangnya kesadaran siswa dalam belajar, disiplin siswa masih rendah dalam mengerjakan tugas, siswa kurang percaya diri dalam belajar secara mandiri, kurang

\section{e. Keunggulan pembelajaran daring}

Pembelajaran daring memiliki beberapa keunggulan antara lain; membawa suasana baru bagi siswa yang biasanya melalukan proses belajar mengajar di kelas secara konvensional dan bertransformasi ke pembelajaran daring. Melatih siswa agar lebih mandiri dalam belajar. Fleksibel waktu dan tempat, pembelajaran bisa dilakukan dimana saja asalkan ada koneksi internet, melatih siswa maupun guru untuk lebih menguasai teknologi informasi yang terus berkembang, dan siswa bisa mengakses materi pembelajaran sewaktu-waktu kapan saja.

\section{f. Kelemahan pembelajaran daring}

$$
\text { Pelaksanaan pembelajaran }
$$

daring memiliki beberapa kelemahan antara lain; kurang cepatnya umpan balik yang dibutuhkan dalam kegiatan belajar mengajar dan sulit dalam menentukan penilaian yang sesuai, siswa maupun guru perlu waktu lebih lama untuk menyesuaikan dengan adanya perubahan sistem pembelajaran, terkadang membuat beberapa orang merasa tidak nyaman, dan menyebabkan pembelajaran tidak bisa maksimal karena siswa sulit dalam menyerap ilmu pengetahun 
yang diajarkan (Pangondian, 2019: 57).

Hal ini selaras dengan hasil wawancara dengan guru Pendidikan Agama Buddha, pembelajaran daring memiliki kelemahan yaitu sarana prasana yang belum merata, siswa menjadi cenderung malas, siswa merasa bosan dan jenuh belajar dari rumah, pembelajaran secara daring menimbulkan rasa setres pada siswa dengan banyaknya tugas yang harus dikerjakan ditambah lagi dengan harus berdiam diri dirumah, akses internet yang relatif susah sehingga siswa kesulitan dalam mengikuti pembelajaran, serta kurangnya interaksi siswa dengan guru sehingga siswa sulit dalam memahami materi pembelajaran.

\section{g. Faktor pendukung}

Keberhasilan sebuah kegiatan pembelajaran dipengaruhi dua faktor utama yaitu faktor internal dan faktor eksternal. Faktor internal, yakni keadaan atau kondisi jasmani dan rohani siswa meliputi; motivasi, minat, bakat, kecerdasan dan sebagainya sedangkan faktor eksternal, yakni kondisi lingkungan di sekitar siswa (Purnomo, 2019: 74). Faktor yang paling utama dalam Pelaksanaan pembelajaran daring adalah faktor yang berasal dari dalam diri siswa sendiri untuk melakukan pembelajaran, kemandirian belajar dan kesadaran siswa dalam belajar secara mandiri sangat mempengaruhi keberhasilan pada pembelajaran daring. Adanya inisiatif atau kesadaran dalam diri untuk menyelesaikan tugas yang diberikan dan kesiapan siswa dalam melakukan pembelajaran secara daring, serta harus didukung dengan sarana prasana yang memadai seperti ketersediaan gawai, handphone android, laptop, ketersedian kuota internet, jaringan internet yang memadai agar pembelajaran dapat berjalan secara maksimal.

\section{h. Faktor penghambat}

Faktor penghambat dalam pembelajaran daring adalah kemandirian belajar siswa yang masih rendah, dibuktikan dengan siswa menjadi cenderung malas dalam mengikuti pembelajaran, masih kurang kesadaran siswa dalam mengerjakan tugas. Belum siapnya melakukan pembelajaran daring, ditunjukan siswa dan guru memerlukan waktu untuk menyesuaikan kebiasaan baru, dimana yang awalnya proses pembelajaran dilakukan secara konvensional dan harus berubah ke pembelajaran secara jarak jauh atau online, guru tidak bisa menjelaskan secara maksimal karena perubahan cara dan sistem 
pembelajaran, masih rendah daya beli kuota internet, keberadaan tempat tinggal siswa yang tersebar dibeberapa daerah, menjadikan kemampuan dalam menerima signal juga berbedabeda, bahkan ada beberapa tempat tidak ada signal sama sekali, yang menjadikan siswa harus pergi mencari tempat yang memiliki signal. Sehingga dibutuhkan fasilitas pendukung untuk memaksimalkan hasil belajar siswa dalam pembelajaran daring.

\section{Hasil belajar siswa pada mata} pelajaran Pendidikan Agama Buddha di SMA Bhakti Karya Kaloran

\section{Kabupaten Temanggung}

Hasil belajar adalah sebuah pencapaian yang diperoleh siswa dalam proses dan kegiatan pembelajaran dari awal sampai akhir, dibuktikan dengan pencapaian yang diperoleh siswa dengan melibatkan aspek pengetahuan, sikap, maupun keterampilan. Hasil belajar siswa saat pembelajaran daring pada mata pelajaran Pendidikan Agama Buddha memang mengalami penurunan dilihat dari perbandingan nilai siswa dari semester ganjil dan semester genap tahun ajaran 2020/2021, hal ini karena memang pembelajaran secara daring berbeda dengan pembelajaran secara tatap muka langsung, pada saat pembelajaran daring ada beberapa masalah dan hambatan yang dialami siswa dan guru dalam proses pelaksanaan kegiatan belajar mengajar. Proses belajar mengajar dengan memanfaatkan jaringan internet yang dilakukan guru dan siswa secara jarak jauh belum didukung dengan fasilitas yang memadai, hal ini wajar kalau pembelajaran belum bisa mencapai hasil secara maksimal. Pelaksanaan pembelajaran secara daring memang sejatinya dikatakan belum efektif karena tidak dapat mencapai target KI dan KD secara maksimal.

Pada kondisi yang saat ini dengan adanya pandemi Covid-19 memang pembelajaran tidak dibebani pada ketercapaian KI dan KD, agar siswa tidak terbebani dengan tuntutan ketercapaian hasil belajar pada saat belajar dari rumah. Dampak diberlakukannya pembelajaran daring terhadap ketercapaian hasil belajar siswa memang mengalami penurunan karena dinilai sistem pembelajaran secara daring masih kurang efektif.

Pembelajaran daring menyebabkan siswa dan guru tidak bisa bertatap muka dan berinteraksi secara langsung pada saat pembelajaran, sehingga menyebabkan kurangnya pemahaman siswa ketika melakukan proses belajar secara daring. Hal ini dikarenakan siswa kesulitan dalam memahami pelajaran yang diajarkan oleh guru karena tidak bertatap muka langsung, menunjukkan bahwa ketidaksiapan siswa dengan kebiasaan baru, melakukan pembelajaran secara daring. 
Keberhasilan sebuah kegiatan pembelajaran dapat diukur dan dilihat dengan sejauhmana tingkat pemahaman siswa terhadap materi yang sudah diberikan pada saat proses pembelajaran. Keberhasilan belajar dan latihan dalam Anguttara Nikaya II, 160 ditandai dengan pengertian dan ketrampilan (patisambhida) dalam hal: 1) Memahami maksud dan tujuan, mampu menjelaskan dan menjabarkan secara rinci, dan mampu mempertimbahkan konsekuensinya; 2) Memahami inti sari atau mampu merangkum, dan menganalisis atau dapat menunjukkan penyebabnya; 3) pandai dalam memilih kata atau menggunakan tutur kata yang tepat dalam menyampaikan sesuatu dan mudah untuk dipahami dengan benar; 4) ketangkasan dalam cara mengatasi dan menyelesaikan sebuah masalah yang muncul secara mendadak (Mukti, 2003: 328). Ketercapaian hasil belajar siswa pada mata pelajaran Pendidilan Agama Buddha saat pembelajaran daring memang mengalami penurunan. Penurunan pada segi pemahaman materi, dikarenakan penjelasan yang diberikan sangat terbatas dengan media yang ada, sehingga siswa kesulitan dalam menangkap dan memahami materi pembelajaran.

\section{KESIMPULAN}

Berdasarkan hasil analisis data dan pembahasan, maka penulis dapat menarik kesimpulan dalam penelitian ini sebagai berikut; Pelaksanaan pembelajaran daring pada mata pelajaran Pendidikan Agama Buddha di SMA Bhakti Karya Kaloran sudah berjalan dengan cukup baik. Pembelajaran daring dilaksanakan siswa dengan menggunakan aplikasi whatsapp. Metode yang digunakan pada saat pembelajaran daring adalah metode ceramah dan penugasan. Adanya faktor penghambat saat pembelajaran daring seperti belum meratanya fasilitas pendukung dan masih kurangnya motivasi siswa saat pembelajaran daring sehingga pembelajaran masih kurang efektif.

Hasil belajar siswa pada mata pelajaran Pendidikan Agama Buddha saat pembelajaran daring mengalami penurunan dilihat dari perbandingan nilai siswa dari semester ganjil dan semester genap tahun ajaran 2020/2021, hal ini karena ada beberapa faktor yang mempengaruhi seperti fasilitas pendukung yang belum merata, keberadaan siswa yang tersebar dibeberapa tempat yang minim signal, siswa kesulitan dalam memahami materi, kesadaran siswa akan tanggung jawabnya dalam mengerjakan tugas masih kurang, dan faktor lingkungan di sekitar siswa yang kurang mendukung sehingga menyebabkan menurunnya hasil belajar siswa.

\section{SARAN}

1. Siswa

Penelitian ini diharapkan dapat memberikan gambar tentang proses 
pelaksanaan pembelajaran secara daring. Agar siswa lebih bersemangat dan memiliki motivasi yang tinggi dalam mengikuti proses pembelajaran dengan baik, sehingga dapat mencapai hasil belajar yang maksimal.

\section{Guru}

$$
\text { Guru diharapkan dapat }
$$
mengembangkan media yang digunakan dalam pembelajaran agar proses kegiatan pembelajaran tetap dapat berjalan dengan efektif walaupun dilakukan secara daring/online, lebih intens berkomunikasi dengan siswa. Guru hendaknya dapat menerapkan metode yang sesuai agar siswa lebih bisa menerima dan memahami pembelajaran.

\section{Sekolah}

Melalui penelitian ini diharapakan sekolah dapat melengkapi fasilitas pendukung dan sarana prasarana yang memadai, untuk menunjang guru dalam melaksanakan pembelajaran secara daring agar dapat berjalan dengan efektif dan efesien.

\section{DAFTAR PUSTAKA}

Depdiknas. (2003). Undang-Undang Republik Indonesia Nomor 20 Tahun 2003 Tentang Sistem Pendidikan Nasional. Jakarta: Depdiknas.

Dimyati \& Mudjiono. (2013). Belajar dan Pembelajaran. Jakarta: Rineka Cipta.

Gunawan. I. (2015). Metode Penelitian Kualitatif: Teori dan Praktik. Jakarta: Bumi Aksara.
Mukti, Krisnanda Wijaya. (2003). Wacana Buddha Dhamma. Jakarta: Yayasan Dharma Pembangunan.

Nugrahani, Farida. (2014). Metode Penelitian Kualitatif dalam Penelitian Pendidikan Bahasa. Solo: Cakra Books.

Pangondian, Roman A. (2019). Faktor-Faktor Yang Mempengaruhi Kesuksesan Pembelajaran Daring Dalam Revolusi Industri 4.0. Seminar Nasional Teknologi Komputer \& Sains (SAINTEKS). 57.

Purnomo, Halim. (2019). Psikologi Pendidikan. Yogyakarta: LP3M UMY.

Purwanto, A., dkk. (2020). Studi Eksploratif Dampak Pandemi COVID-19 Terhadap Proses Pembelajaran Online di Sekolah Dasar. EduPsyCouns: Journal of Education, Psychology and Counseling, 2(1), 1-12. https://ummaspul.ejournal.id/Edupsycouns/article/view/3 97.

Putria, dkk. (2020). Jurnal basicedu. Analisis Proses Pembelajaran Dalam Jaringan (DARING) Masa Pandemi COVID-19 Pada Guru Sekolah Dasar, 4(4), 861-872. https://doi.org/10.31004/basicedu.v4i 4.460.

Riyana, C. (2019). Produksi Bahan Pembelajaran Berbasis Online. Universitas Terbuka.

Sobron, dkk. (2019). Pengaruh Daring Learning terhadap Hasil Belajar IPA Siswa Sekolah Dasar. Seminar Nasional Sains \& Entrepreneurship, 1(1), 1-5. http://conference.upgris.ac.id/index.p $\mathrm{hp} /$ snse/article/view/204/136. 
Syarifudin, A. S. (2020). Impelementasi Pembelajaran Daring Untuk Meningkatkan Mutu Pendidikan Sebagai Dampak Diterapkannya Social Distancing. Jurnal Pendidikan Bahasa Dan Sastra Indonesia Metalingua, 5(1), 31-34. https://doi.org/10.21107/metalingua. v5i1.7072.

Isman. (2017). Pembelajaran Moda dalam Jaringan (Moda Daring). The Progressive and Fun Education Seminar, 586-588.

Widodo, U., Ngadat, \& Subandi, A. (2021). Designing Interactive Audio-Visual Instructional Media Based On Value Clarification Technique ( VCT ). Journal of Education Technology, 5(4), 611-618. https://doi.org/10.23887/jet.v5i4.40412

Yodha, S., Abidin, Z., \& Adi, E. (2019). Persepsi Mahasiswa Terhadap Pelaksanaan E-Learning Dalam Mata Kuliah Manajemen Sistem Informasi Mahasiswa Jurusan Teknologi Pendidikan Universitas Negeri Malang. Jurnal Kajian Teknologi Pendidikan, 2(3), 181-187. https://doi.org/10.17977/um038v2i32019 p181 